\title{
Evaluation of three commercial kits for mycoplasma NAT assays: selection and quality improvement
}

\author{
Fabien Dorange*, Frédérick Le Goff, Nicolas Dumey \\ From 22nd European Society for Animal Cell Technology (ESACT) Meeting on Cell Based Technologies \\ Vienna, Austria. 15-18 May 2011
}

\section{Background}

Mycoplasma testing on cell lines or biological products used to be performed based on classical methods such as agar and broth medium and/or indicator cell culture. However, these methods require a long incubation period and are not adapted for samples, like live-attenuated vaccine viruses (which can not completely be neutralized) or cell therapy products (with short shelf life). NAT assays have several advantages including rapidtime to results, robustness and sensitivity. The European Pharmacopoeia updated the 2.6.7 section by adding the detection of Mycoplasma with NAT methods as an alternative to one or both classical methods.

Texcell's offers for Mycoplasma testing, which already included classical methods, were incremended with NAT assay. For this purpose, 3 commercial kits based on NAT assay were evaluated based of their claim to meet the European Pharmacopeia guidance for nucleic acid amplification techniques for Mycoplasma testing, including sensitivity and range of detection: CytoCheck ${ }^{\mathrm{B}}$ from Greiner, MycoTOOL ${ }^{\circledR}$ from Roche, MycoSEQ ${ }^{\circledR}$ Mycoplasma detection kit from Life Technologies.

\section{Material and methods}

5 mycoplasma species were chosen among the 9 strains listed in the European Pharmacopeia.

Mycoplasma Pneumoniae: CIP 103766T

Mycoplasma Hyorhinis: ATCC 179891

Acholeplasma Laidlawii: ATCC 23206

Mycoplasma Orale: provided by Greiner Bio-One

Mycoplasma Synoviae: provided by Greiner Bio-One
* Correspondence: dorange@texcell.fr Texcell, Evry, France, 91058
$1 \mathrm{ml}$ of different concentrations of mycoplasma were tested according to the supplier's instructions.

\section{Results}

For the mycotool results, none of the mycoplasma species tested were detected above the required limit of detection of $10 \mathrm{cfu} / \mathrm{ml}$. Investigations showed that quantity of nucleic acids in our experimental design was too small to be efficiently recovered with the precipitation based extraction procedure. Indeed, the mycoTOOL ${ }^{\circledR}$ kit was designed to be used in conjonction with $\mathrm{CHO}$ cells $\left(5 \times 10^{6}\right.$ cells $\left./ \mathrm{ml}\right)$, acting like carrier DNA for the precipitation step. Since this study, the kit's supplier has included a carrier DNA for samples containing low level of nucleic acid.

Both remaining selected kits $\left(\right.$ MycoSEQ ${ }^{\circledR}$ and Cyto$\mathrm{Check}^{\mathbb{R}}$ ) met the sensitivity parameters and were compared (Table 1).

Although these kits use a different technology, similar results (sensitivity, range of detection) were obtained. The lower sensitivity observed with the MycoSEQ ${ }^{\circledR}$ kit for M. Pneumoniae is explained by the presence of nonviable mycoplasmas induced during thawing/freezing cycle for stocks preparation.

According to its safer use (no post-amplification handling), its lower cost and quantitation possibilities, the MycoSEQ ${ }^{\circledR}$ kit was preferred.

Performance validation was conducted in Texcell facilities using the MycoSEQ ${ }^{\circledR}$ Mycoplasma detection kit.

\section{Conclusion: selection of a high performance kit and quality improvement}

Although two of the selected kits show similar results, the $\mathrm{MycoSEQ}^{\circledR}$ kit was chosen for its lower risk of cross contamination. However, all the tested kits (including 
Table 1 Comparison of the MycoSEQ ${ }^{\circledR}$ Mycoplasma detection kit and CytoCheck ${ }^{\circledR}$ kit.

\begin{tabular}{|c|c|c|c|}
\hline \multirow[b]{2}{*}{ Parameters } & \multicolumn{2}{|c|}{ KIT supplier } & \multirow[b]{2}{*}{ Priority } \\
\hline & MycoSEQ $^{\circledR}$ & CytoCheck $^{\circledR}$ & \\
\hline & Applied Biosystems & Greiner & \\
\hline tested sensitivity & $<10 \mathrm{CFU} / \mathrm{ml}$ & $<10 \mathrm{CFU} / \mathrm{ml}$ & 1 \\
\hline Species coverage & $>90$ & 41 identified & 2 \\
\hline Time to results & Same day & Same day & 3 \\
\hline Contamination prevention & No post-amplification sample handling & post-amplification sample handling & 4 \\
\hline Reagent price ratio per test & 1 & 10 & 5 \\
\hline Equipment & Real-Time PCR 7500 & PCR machine scanner & 6 \\
\hline quantitation & yes & no & 7 \\
\hline
\end{tabular}

the selected one) suffer from a lack of appropriate extraction controls. Therefore, tests performed systematically at Texcell include viable mycoplasmas (positive and inhibitory controls). This Texcell's added value improves the quality of the whole process from the first concentration step (centrifugation) to the qPCR results. At Texcell, in 2010, the first samples were tested with success in a "GMP regulation context".

Published: 22 November 2011

doi:10.1186/1753-6561-5-S8-P127

Cite this article as: Dorange et al.: Evaluation of three commercial kits

for mycoplasma NAT assays: selection and quality improvement. BMC

Proceedings 2011 5(Suppl 8):P127.

Submit your next manuscript to BioMed Central and take full advantage of:

- Convenient online submission

- Thorough peer review

- No space constraints or color figure charges

- Immediate publication on acceptance

- Inclusion in PubMed, CAS, Scopus and Google Scholar

- Research which is freely available for redistribution

Submit your manuscript at www.biomedcentral.com/submit
C Biomed Central 